\title{
Canadian Association of Neurosciences Review: Regulation of Myelination by Trophic Factors and Neuron-Glial Signaling
}

\author{
Giorgia Melli, Ahmet Höke
}

\begin{abstract}
Myelination in the nervous system is a tightly regulated process that is mediated by both soluble and non-soluble factors acting on axons and glial cells. This process is bi-directional and involves a variety of neurotrophic and gliotrophic factors acting in paracrine and autocrine manners. Neuron-derived trophic factors play an important role in the control of early proliferation and differentiation of myelinating glial cells. At later stages of development, same molecules may play a different role and act as inducers of myelination rather than cell survival signals for myelinating glial cells. In return, myelinating glial cells provide trophic support for axons and protect them from injury. Chronic demyelination leads to secondary axonal degeneration that is responsible for long-term disability in primary demyelinating diseases such as multiple sclerosis and inherited demyelinating peripheral neuropathies. A better understanding of the molecular mechanisms controlling myelination may yield novel therapeutic targets for demyelinating nervous system disorders.
\end{abstract}

RÉSUMÉ: Régulation de la myélinisation par des facteurs trophiques et par la signalisation de la névroglie. La myélinisation du système nerveux est un processus étroitement régulé, qui est médié par des facteurs solubles et non solubles agissant sur les axones et les cellules gliales. Ce processus est bidirectionnel et implique des facteurs neurotrophes et gliotrophes variés agissant de façon paracrine et autocrine. Des facteurs trophiques dérivés des neurones jouent un rôle important dans le contrôle de la prolifération et de la différenciation précoce des cellules gliales myélinisantes. À des étapes ultérieures du développement, les mêmes acteurs peuvent jouer un rôle différent et agir comme inducteurs de la myélinisation plutôt que dans la signalisation de la survie cellulaire des cellules gliales myélinisantes. En retour, les cellules gliales myélinisantes fournissent un support trophique aux axones et les protègent de lésions. Une démyélinisation chronique entraîne une dégénérescence axonale secondaire qui est responsable de l'invalidité à long terme observée dans les maladies démyélinisantes primaires comme la sclérose en plaques et les neuropathies périphériques démyélinisantes héréditaires. Une meilleure compréhension des mécanismes moléculaires contrôlant la myélinisation pourrait identifier des cibles thérapeutiques nouvelles pour le traitement des maladies démyélinisantes du système nerveux.

Can. J. Neurol. Sci. 2007; 34: 288-295

Myelination of the nervous system is a complex and highly regulated process that is still far from completely understood. The timing of myelination is precise and specific for species and for regions of the nervous system, suggesting that a highly localized signaling mechanism regulates the whole process. ${ }^{1}$ Myelination is tightly regulated by reciprocal signaling between the myelinating glial cells, oligodendrocytes in the central nervous system (CNS) and Schwann cells in the peripheral nervous system (PNS), and their target axons. ${ }^{2}$ In recent years, an increasing number of studies examined the role of multiple cell- signaling pathways involved in differentiation and commitment of glial cells to become myelinating cells (reviewed in

From the Neuromuscular Diseases Unit (GM), IRCSS Foundation Neurological Institute Carlo Besta, via Celoria, 1120133 - Milan, Italy; Departments of Neurology and Neuroscience (AH), Johns Hopkins University, School of Medicine, Baltimore, MD, USA.

Received December 4, 2006. AcCePted in finAl fORm April 16, 2007. Reprint requests to: Ahmet Höke, Johns Hopkins Hospital, Department of Neurology 600 N. Wolfe St., Rm \#: Path 509, Baltimore, MD, 21287, USA. 
references 3-5). This body of work is being complemented by studies on how axon-glia interaction dictates the myelination process and which axons are selected for myelination. ${ }^{2,6-9}$ Yet, many unanswered questions remain. For example, similarities and differences between peripheral and central myelination remain poorly understood. The role of myelin in maintenance and health of the axon in the adult animal and the processes that underlie demyelination and remyelination in disease states are not well characterized. These are important questions to answer as they may hold clues to the pathogenesis of many CNS and PNS diseases such as multiple sclerosis and peripheral neuropathies.

Membrane-bound and diffusible factors are thought to be involved in regulation of myelin formation. These bi-directional factors include both neuron/axon-derived factors and gliaderived factors. A key axon-derived regulator of myelination is the neuregulin family of glial growth factors. ${ }^{5,6}$ Neuregulins play key roles in maturation of Schwann cells and dictate myelination and myelin thickness. These axon-derived growth factors are complemented by a host of neurotrophic factors that often have both paracrine and autocrine action on the glial cells and neurons. ${ }^{10}$ Neurotrophic factors are polypeptides required for survival of various neuronal populations. They can be divided in three major groups according to the receptor they bind to: i) classical neurotrophins that include nerve growth factor (NGF), brain derived neurotrophic factor (BDNF), neurotrophin 3 (NT3 ) and neurotrophin 4/5 (NT-4/5), are small basic polypeptides that act through a high-affinity tyrosine kinase receptor family; ii) neurokines, including ciliary neurotrophic factor (CNTF) and leukemia inhibitory factor (LIF), act at receptors that have both common (gp130, LIFR $\beta$, ) and specific (CNTFR- $\alpha$ ) transmembrane subunits; iii) transforming growth factors (TGF)- $\beta$ and related glial cell line derived neurotrophic factor (GDNF) family of neurotrophic factors that act through a transmembrane ligand binding subunit (GDNFR- $\alpha$ ) and a signaling tyrosine kinase subunit (Ret). In this review, we will focus on recent advances made on the key regulators of gliogenesis and myelination, with special attention to differences and similarities between the PNS and CNS.

\section{Gliogenesis and differentiation of myelinating cells}

In the PNS, Schwann cells originate from neural crest cells, passing through two intermediate cell types, Schwann cell precursors and immature Schwann cells. ${ }^{11}$ Axon-derived type III neuregulin-1, signaling through the ErbB3 and ErbB2 transmembrane tyrosine kinases, is essential for regulating the embryonic development of Schwann cell lineage. ${ }^{12,13}$ Migrating neuronal crest cells contact axons and migrate along the forming nerve bundles and neuregulin-1 type III is essential at this stage. After transition to Schwann cell precursors, neuregulin-1 sustains proliferation and survival of these cells ${ }^{14}$ (Table 1). Studies on knockout mice lacking neuregulin-1, or its receptors ErbB2 or ErbB3 revealed the essential role for neuregulin-1 signaling in genesis and migration of Schwann cells. ${ }^{15,16}$

After differentiation, depending on which axons they are associated with, Schwann cells become myelinating or nonmyelinating and at this point the neuregulin signaling system is not required for survival, but remains an important regulator of
Table 1: Role of growth factors in gliogenesis

\begin{tabular}{|c|c|c|c|c|c|}
\hline & $\begin{array}{l}\text { Growth } \\
\text { Factors }\end{array}$ & Migration & Proliferation & Differentiation & Survival \\
\hline \multirow{2}{*}{ Schwann Cell Precursors } & NRG1 III & + & + & & + \\
\hline & GDNF & + & + & & \\
\hline \multirow{3}{*}{ Mature Schwann Cells } & NT3 & & & & + \\
\hline & IGF2 & & & & + \\
\hline & PDGF BB & & & & + \\
\hline \multirow{5}{*}{$\begin{array}{l}\text { Oligodendrocyte } \\
\text { Precursors }\end{array}$} & PDGF & + & + & & + \\
\hline & TGF $\beta$ & & & + & \\
\hline & EGF & & & + & \\
\hline & NT3 & & + & + & \\
\hline & NRG & & + & & + \\
\hline
\end{tabular}

myelin sheath thickness. ${ }^{7}$ Unlike the precursors, mature Schwann cells in adult nerves survive in the absence of axons, suggesting an important change in regulation of survival. The key regulators of this survival are not fully elucidated but recent data implicates neuregulin-1/ErbB2 signaling at the earliest stages of Wallerian degeneration. At the initial stages of denervation, injured axons release neuregulin-1 and activate ErbB2 on Schwann cells which result in activation of the cell proliferation and survival pathways. ${ }^{17}$ However, this is not likely to be the only pathway important for survival of denervated Schwann cells. An autocrine regulatory mechanism may allow mature Schwann cells survive through prolonged denervation injury and provide a permissive environment for repair. Although not all factors for Schwann cell survival in this autocrine loop are known, current data point to the importance of insulin-like growth factor 2 (IGF-2), ${ }^{18}$ platelet derived growth factor-BB (PDGF-BB $)^{19-21}$ and NT-3, which together with laminin, support long-term Schwann cell survival ${ }^{22}$ (Table 1).

In CNS, local availability of growth factors is the principal regulator of proliferation, migration and differentiation of glial precursors. Many factors including PDGF, bFGF, IGF-1, IGF-2, NT-3, CNTF and LIF have been implicated in this process (reviewed in ${ }^{23}$ )(Table 1). Most of the data are from in vitro work; PDGF is mitogenic for brain and optic nerve oligodendrocyte progenitors and in the presence of bFGF inhibits differentiation. ${ }^{24}$ Likewise, TGF $\beta$ and epidermal growth factor (EGF) stimulate differentiation and maturation of progenitors in vitro. ${ }^{25}$ Neurotrophin 3, however, has been shown to control oligodendrocyte numbers and maturation in the developing optic nerve in vivo. ${ }^{26,27}$ While the essential role of neuregulin signaling in Schwann cell development has been clarified, the role of neuregulin signaling in oligodendrocyte development and maturation is less clear and controversial. During early stages of development, neuregulin acts as a mitogen on oligodendrocyte precursors and inhibits differentiation into the myelinating type. A study in developing optic nerve showed that neuregulin signaling was important in controlling the numbers of oligodendrocytes, ${ }^{28}$ but it was unclear as how the neuregulins were involved in regulating the myelination of terminally differentiated oligodendrocytes. A study by Colognato and 
colleagues showed that signaling by the axonal laminin through the alpha- 6 integrin receptor on oligodendrocytes switches neuregulin cell survival signal from phosphatidylinositol-3-OH kinase pathway to dependence on the mitogen-activated kinase pathway. ${ }^{29}$ This allows the neuregulin signaling to act on the myelination pathway in oligodendrocytes. Furthermore, another recent study implicated neuregulin signaling in the terminal differentiation of oligodendrocytes; transgenic mice lacking ErbB2 receptor have widespread hypomyelination due to reduction in terminal differentiation of oligodendrocytes. ${ }^{30}$ Another axon-derived signal that regulates oligodendrocyte differentiation is the Notch signaling pathway. Oligodendrocyte precursors express the Notch 1 receptor and the interaction with Jagged 1, expressed at the axonal surface, induces the inhibition of their differentiation into oligodendrocytes. ${ }^{31}$ Subsequently it was shown that the axonal adhesion molecule contactin is an alternative Notch ligand and promotes oligodendrocyte differentiation. ${ }^{32}$ This represents another example of a tight spatial regulation of glial cell differentiation mediated by axonal contact.

\section{Selection of axons and myelin formation}

During development, selected axons are myelinated, while others remain unmyelinated. How this selection is done and what are the determining factors are not fully identified. Clearly, the axonal characteristics, especially axonal caliber, are important in determining the myelination fate. This has been shown for both oligodendrocytes $^{33}$ and Schwann cells. ${ }^{34,35}$ Axonal caliber is not however, the only determining factor as small caliber unmyelinated axons can be myelinated in the presence of neurotrophic factors (see below and ${ }^{36}$ ). How the axonal diameter information is translated to a signal for myelinating cells is unclear. The observation that primary sensory and lower motor neuron axons maintain the same myelinated or unmyelinated phenotype along their length in CNS and PNS, has led to the hypothesis that myelination is regulated by common axonal signals in PNS and CNS. ${ }^{37}$ However, this hypothesis may be proven wrong. Substantial differences exist between Schwann cells and oligodendrocytes; primarily the fact that Schwann cells myelinate only one axon and the oligodendrocytes myelinate multiple axons with variable sizes. A study on mouse mutants with diminished axonal calibers due to deficiency of neurofilaments showed that in PNS the myelin thickness was unchanged from controls, with abnormally thicker myelin sheath for axons with smaller diameters suggesting that Schwann cells recognize intrinsic signals from the axons to determine myelin thickness irrespective of the axon size. Yet, the same axons within the CNS showed thinner myelin thickness suggesting that axonal caliber is a more important determinant of myelin thickness by oligodendrocytes. ${ }^{38}$

Other studies on neurotrophins support the hypothesis that myelination is differentially regulated in PNS and CNS. Recent studies have shown that neurotrophins, in addition to their role as promoters of development and survival of glial cells, are fundamental regulators of the axonal signals that control myelination and that they exert different effects on Schwann cells and oligodendrocytes. For example, NGF promotes myelination of TrkA positive dorsal root ganglion neurons by Schwann cells and inhibits myelination by oligodendrocytes. ${ }^{39}$ In vitro studies using dorsal root ganglion (DRG) and Schwann cell co-culture and in vivo mouse sciatic nerve show that BDNF levels correlate with myelin formation and the addition of exogenous BDNF enhances myelination. ${ }^{40}$ In the same study, NT-3 significantly inhibited myelin production, and removal of endogenous NT-3 resulted in enhancement of the process similar to that obtained by addition of BDNF. In another study, Cosgaya and colleagues have shown that myelin formation in the PNS is blocked in the absence of functional low-affinity neurotrophin receptor, p75NTR, and enhanced by blocking trkC activity. ${ }^{41}$ Furthermore, they showed that promotion of myelination by BDNF is mediated by $\mathrm{p} 75 \mathrm{NTR}$ receptor and that inhibition of myelination by NT-3 is mediated by trkC. Altogether, these studies led to a model for control of PNS myelination by neurotrophins and their receptors. NT-3, BDNF, p75NTR and trkC are all expressed in premyelinating nerves, NT-3 and its receptor trkC provide an inhibitory signal for myelin gene expression and keep Schwann cells in a proliferative, premyelinogenic state. Later, when Schwann cells establish a one to one relation with axons, NT-3 and trkC are reduced, while BDNF and p75NTR expression remain high, promoting myelin formation. ${ }^{42}$ The p75NTR receptor is rapidly downregulated at the onset of myelination; ${ }^{43}$ therefore, it is likely to promote the initial axon-glia interaction that precedes myelination. High-

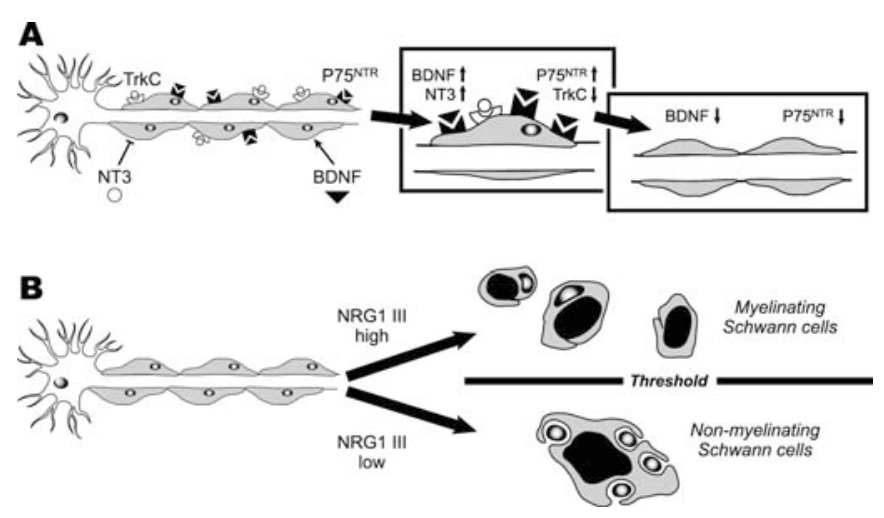

Figure 1: Regulation of myelination in the PNS. 1A) During premyelination, BDNF, NT3 and their receptors p75NTR and TrkC are all expressed and NT3-TrkC signaling inhibits myelin gene expression, keeping Schwann cells in proliferative, premyelinogenic state. Later when Schwann cells establish a one-to-one relationship with axons, NT3 is downregulated, while BDNF expression remains high, promoting myelination. Once mature internodes are formed BDNF and $p 75 N T R$ are downregulated. 1B) Levels of neuregulin 1 type III (NRG1) on axons determine Schwann cell phenotype with a threshold level triggering myelination: low neuregulin 1 type III on axons induce a nonmyelinating pattern and the formation of Remak bundles, high levels of neuregulin 1 type III induce a one-to-one relationship and myelination by Schwann cells. 
Table 2: Role of growth factors in myelination

\begin{tabular}{l|c|c}
\hline & PNS Myelination & CNS Myelination \\
\hline BDNF & + & $+/-$ \\
\hline NT3 & - & $\boldsymbol{+}^{*}$ \\
\hline NGF & + & - \\
\hline GDNF & + & + \\
\hline CNTF & & + \\
\hline LIF & & + \\
\hline Oncostatin M & & + \\
\hline Cardiotrophin & & \\
\hline
\end{tabular}

* in combination with BDNF

level expression of p75NTR is required for myelination to proceed properly. Once mature myelin internodes are formed, both BNDF and p75NTR are down regulated ${ }^{41}$ (Figure 1A). In this study, the BDNF secreted from the axons was the paracrine regulator of myelination supporting the other observations that in the PNS neurotrophic signals separated from the axonal size are important determinants of myelination.

However, BDNF is not the only neurotrophic factor to induce myelination in vivo. An early study on the effects of partial denervation in the salivary gland showed that normally unmyelinated axons were myelinated when partial denervation was performed. ${ }^{44}$ This study suggested that the remaining intact axons were exposed to higher levels of target-derived NGF, therefore underwent myelination. In another study, exogenous application of high levels of GDNF induced myelination in otherwise unmyelinated small fiber sensory DRG neurons. ${ }^{36} \mathrm{~A}$ more recent study showed that GDNF regulates Schwann cell function prior to myelination and at early stages of myelin formation in vitro, by utilizing GDNF-family receptor-alpha (GFR $\alpha 1)$ and neural cell adhesion molecule (NCAM) as receptors. ${ }^{45}$ The study proposes a model for GDNF signaling that activates ERK (extracellular signal-regulated kinases) with subsequent increased proliferation and migration of Schwann cells. However, it is unclear if the enhanced myelination induced by GDNF in co-culture of Schwann cells and DRG neurons is directly due to its action on glial cells or secondary through its action on axons. This issue was not resolved in the other study on GDNF and myelination. ${ }^{36}$

An intriguing possibility is that neurotrophins act indirectly on axons by stimulating the expression of neuregulin 1 type III, which has been shown to determine the binary choice of Schwann cell phenotype with a threshold level triggering myelination ${ }^{7}$ (Figure 1B). Supporting this hypothesis, an in vitro study has shown that GDNF and NGF induce a rapid release of neuregulin 1 from dorsal root ganglion sensory and spinal motor neurons. ${ }^{46}$

These studies on neurotrophins and PNS myelination are in contrast to the CNS myelination studies. As mentioned above NGF does not induce myelination by oligodendrocytes and a study by Stankoff and colleagues showed that members of the GDNF family and classic neurotrophins, NGF, BDNF and NT3, did not have promyelinating effect on oligodendrocytes. ${ }^{47}$ Moreover, they showed that neurocytokines, CNTF, LIF, cardiotrophin-1 and oncostatin $\mathrm{M}$, induced myelination in oligodendrocytes. Ciliary neurotrophic factor acted on oligodendrocytes by favoring their final maturation through the Janus kinase pathway. In contrast, an animal study has shown that BDNF-deficient mice have marked hypomyelination in the $\mathrm{CNS}^{48}$ and BDNF and NT3, in combination, enhanced oligodendrocyte myelination in vitro (Table 2).

\section{Regulation of myelin thickness}

Neuregulin-1 has been identified as a key regulator of myelin thickness. Through the interaction with the ErbB receptor tyrosine kinase, it can integrate surface signals and provide axonal information to myelinating cells. Neuregulins are transmembrane and secreted growth factors, encoded by four genes (reviewed in ${ }^{49,50}$ ). Neuregulin-1 has essential functions in the nervous system, heart and breast; while little is known about the function of neuregulin-2, -3 and -4 . There are more than 15 isoforms of neuregulin-1, generated by different promoters and mRNA splicing. These are divided into three classes according to their extra-cellular domain structures and all of them have an active epidermal growth factor-like extracellular domain. They can be secreted or bound to the cell surface as part of a transmembrane isoform; therefore, neuregulins can be used for both long- and short- (cell-to-cell) range signaling. ${ }^{51}$ Neuregulin1 type I and II are shed from the neuronal surface and function as a paracrine signal, while type III remains attached at the cell membrane after cleavage and functions as juxtacrine signal. $^{6}$

As discussed above, neuregulins are essential during early development and maturation of glial cells, but their expression persists in the adult PNS by both sensory and motor neurons. Furthermore, mature Schwann cells express the neuregulin receptors, ErbB2 and ErbB $3 .^{52}$ Tissue specific targeted deletion of ErbB2 in late stage Schwann cells resulted in abnormally thin myelin thickness in peripheral nerves. ${ }^{14}$ The role of neuregulinErbB signaling was later confirmed by another study, which showed that reduced levels of neuregulin-1 type III in mature axons results in reduction of myelin wrapping. ${ }^{9}$ In the same study, overexpression of neuregulin-1 III isoform containing both a transmembrane and cytoplasmic domain in axons caused a dramatic augmentation of myelin thickness, with a consequent reduction of g ratio, while overexpression of neuregulin-1 type I had no effect. This study shows that neuregulin-1 type III itself and not its ErbB receptor is the limiting factor for myelination. These observations were further supported by another recent study that showed that axonal level of neuregulin-1 type III, independently of axon diameter, is the fundamental signal for the determination of the ensheathment fate of axons ${ }^{7}$ (Figure 1B). According to the findings of Michailov and colleagues, ${ }^{9}$ neuregulin-1 regulates the number of myelin wraps, but not the internodal length. Indeed the fact that myelin thickness and internodal length are regulated by different agents may account for the observation that similar size axons have shorter internodal length in facial nerve than sciatic nerve, which is 
subjected to a major stretching during development. ${ }^{51}$ Nevertheless, in a more recent study transgenic mice expressing a dominant negative erbB receptor developed not only thinner myelination, but also abnormal internode length and smaller caliber. ${ }^{53}$ These discordant results could be attributable to the fact that in this study, mice had a complete abolishment of the ErbB receptors compared to previous studies where the mice had reduced levels of the receptors.

In CNS where a single oligodendrocyte myelinates multiple axons of different caliber, it is reasonable to assume that axonal signals are implemented by a high degree of local control within each termination. Although the cellular and molecular mechanisms regulating this local control are unknown, integrins are likely to play an important role. Laminin-2 acting through integrin $\alpha 6-\beta 1$ induces myelin formation in oligodendrocytes in vitro. Mice lacking the laminin $\alpha 2$ chain have thin myelin sheaths and small caliber axons both in the CNS and in the PNS. ${ }^{54}$ This laminin-2 directed myelination signal is mediated through phosphoinositide 3-kinase activity and integrin-linked kinase, ILK (Figure 2).

Another player in CNS myelination is represented by astrocytes, which do not form myelin, but can promote myelination. A recent in vitro study has shown that the cytokine LIF is released by astrocytes in response to ATP liberated from axons firing action potentials. This astrocyte derived LIF, in turn, promotes myelination by mature oligodendrocytes ${ }^{55}$ (Figure 2).

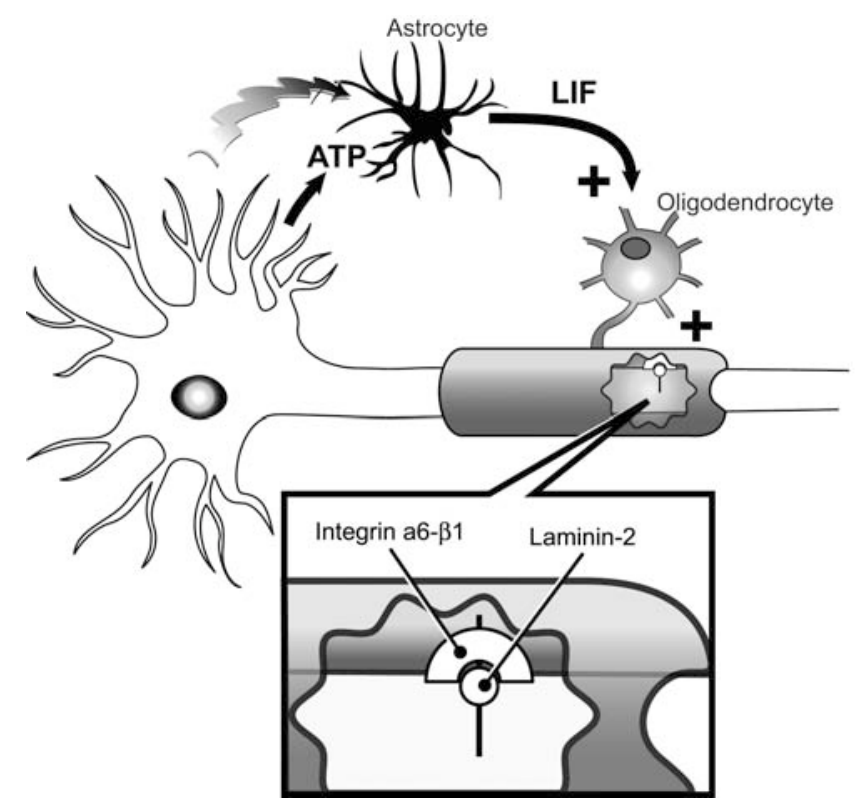

Figure 2: Regulation of myelination in the CNS

LIF promotes myelination in oligodendrocytes; it is released by astrocytes in response to ATP liberated from axons firing action potentials. In the insert, an example of spatial regulation of myelination: axonal laminin- 2 acting through integrin $\alpha 6 \beta 1$ on oligodendrocytes promotes myelination.
These intriguing results reveal that an activity dependent mechanism can regulate myelin production according to functional activity or environmental inputs.

\section{Myelinated glia promote axonal development and survival}

A growing body of evidence indicates that glial derived signals are necessary for neuronal survival during development, regulate the molecular and functional specialization of axons and protect neurons from external insults. The molecular identity of these glia-derived signals and their receptors is just starting to be uncovered.

Saltatory conduction along myelinated nerves depends on accumulation of $\mathrm{Na}$ channels at regularly spaced interruption of myelin, known as nodes of Ranvier. ${ }^{56}$ The nodes are a highly complex structure where the Na channels are associated with cell adhesion molecules and cytoplasmic adaptor proteins. Ensheathment by myelinating glia and node formation are certainly linked together. In fact, the position of the nodes is tightly regulated by the overlying glial cells and is not intrinsically specified by the axon. ${ }^{57,58}$ During the development of peripheral myelinated nerves, $\mathrm{Na}$ channels cluster at sites adjacent to the edges of processes extended by Schwann cells, ${ }^{59}$ indicating that $\mathrm{Na}$ channel clusters are positioned by a direct glia-axon contact. In agreement with this is the demonstration that $\mathrm{Na}$ channel clusters are absent after ablation of Schwann cells, ${ }^{60}$ they are dispersed during acute demyelination, ${ }^{61}$ and reappear during remyelination. ${ }^{62}$ In contrast with the tight requirement for glia-axon contact in PNS, the node formation in CNS might be induced by soluble factors secreted by oligodendrocytes. ${ }^{63,64}$ However, a recent study has identified gliomedin, a glial ligand for axonal adhesion molecules, that is expressed by Schwann cells and accumulates at the edges of myelin processes during development where it aligns with the forming nodes. Furthermore, the study shows that soluble gliomedin induces $\mathrm{Na}$ channel clusters in the absence of Schwann cells. ${ }^{65}$

The influence of glial contact is not restricted to the axonal membrane; in fact, it has been shown that myelinating Schwann cells influence the neurofilament phosphorylation and axonal caliber, and reduce the rate of slow axonal transport. ${ }^{66}$ Similarly in the CNS, oligodendrocytes have been shown to regulate axonal caliber and function; they increase axonal stability and induce local accumulation of neurofilaments within the axons. ${ }^{67,68}$

Nevertheless, the importance of axon-glia interaction is well demonstrated by the consequences of demyelinating disorders such as multiple sclerosis and inherited demyelinating peripheral neuropathies. In both conditions, long-term disabilities are often due to axonal degeneration secondary to chronic demyelination.

Among the neuronal survival signals derived from glia cells, GDNF is certainly a fundamental one. Glial cell line derived neurotrophic factor mRNA is found in Schwann cells precursors and immature Schwann cells in embryonic nerves; it is an important survival factor and mice that lack GDNF lose about $20 \%$ of motor neurons and $23 \%$ of DRG neurons at birth. ${ }^{69,70}$ However, the fact that motor neuron and DRG neuron loss in mice lacking developing Schwann cells is more extensive than that seen in mice missing single neurotrophic factors or their receptors suggests that glia-dependent survival of neuronal 
populations is supported by multiple factors. ${ }^{22}$ Multiple trophic factors may converge on the same intracellular signaling pathway. In CNS neurons, oligodendrocyte-derived neuronal survival signal is likely to be mediated through the PI3 kinase/AKT pathway. ${ }^{71}$

The neuro- or axono-protective role of myelination is best observed in chronic demyelinating diseases of the nervous system. In multiple sclerosis, long-term disability is not proportional to the degree of demyelination but rather to secondary axonal loss. ${ }^{72,73}$ Chronically demyelinated axons may develop a neurotrophic factor deficient state or develop alterations in axonal transport. Experimental data to support these hypotheses is scarce but patients with multiple sclerosis have lower levels of $\mathrm{BDNF}$ in their cerebrospinal fluid. ${ }^{74}$ Furthermore, mice lacking CNTF develop more severe lesions in experimental allergic encephalomyelitis, an animal model of multiple sclerosis, ${ }^{75}$ and administration of exogenous CNTF results in preserved numbers of oligodendrocytes and myelinated axons. ${ }^{76}$ Clearly this is an area that requires intense evaluation to understand why chronic demyelination leads to axonal degeneration and what are the mechanisms for it. Research in this area may open up novel therapeutic targets.

\section{Conclusions}

Myelination is a complex, highly regulated process characterized by the reciprocal interaction between axons and surrounding glia cells that is perfectly integrated in different phases of development. The formation of myelination starts with proliferation, migration and differentiation of glial cells, which is dependent on axonal regulation, continues with myelin production regulated by axonal signals and with the highly specialized formation of node of Ranvier under the control of glial cells and terminates with the survival and maintenance of axons supported by glia. Furthermore, an autocrine survival circuit enables Schwann cells in peripheral nerve to survive in the absence of axons, allowing a successful axonal regeneration following injury.

The molecular identity of these signals and their receptors are being uncovered. Neurotrophic factors are likely to modulate myelination in both PNS and CNS, and are now viewed more correctly as paracrine signals that mediate bi-directional signaling between neurons and glia. An emergent topic is the integration of integrins and growth factors in controlling cell behavior providing a mechanism for temporal and spatial regulation of growth factors effects. ${ }^{77}$ Progress in understanding the cell specific and temporal induction of signals in myelination is likely to be useful for understanding the processes of remyelination and regeneration after injury in both PNS and CNS.

\section{ACKNOWLEDGEMENTS}

This work is supported by National Institute of Neurological Disorders and Stroke (NINDS), The Packard Center for ALS Research at Johns Hopkins and the Adelson Foundation for Medical Research.

\section{REFERENCES}

1. Baumann N, Pham-Dinh D. Biology of oligodendrocyte and myelin in the mammalian central nervous system. Physiol Rev. 2001 Apr;81(2):871-927.

2. Sherman DL, Brophy PJ. Mechanisms of axon ensheathment and myelin growth. Nat Rev Neurosci. 2005 Sep;6(9):683-90.

3. Jessen KR, Mirsky R. Signals that determine Schwann cell identity. J Anat. 2002 Apr;200(4):367-76.

4. Jessen KR, Mirsky R. The origin and development of glial cells in peripheral nerves. Nat Rev Neurosci. 2005 Sep;6(9):671-82.

5. Mirsky R, Jessen KR, Brennan A, Parkinson D, Dong Z, Meier C, et al. Schwann cells as regulators of nerve development. J Physiol Paris. 2002 Jan-Mar;96(1-2):17-24.

6. Nave KA, Salzer JL. Axonal regulation of myelination by neuregulin 1. Curr Opin Neurobiol. 2006 Oct;16(5):492-500.

7. Taveggia C, Zanazzi G, Petrylak A, Yano H, Rosenbluth J, Einheber $\mathrm{S}$, et al. Neuregulin-1 type III determines the ensheathment fate of axons. Neuron. 2005 Sep 1;47(5):681-94.

8. Coman I, Barbin G, Charles P, Zalc B, Lubetzki C. Axonal signals in central nervous system myelination, demyelination and remyelination. J Neurol Sci. 2005 Jun 15;233(1-2):67-71.

9. Michailov GV, Sereda MW, Brinkmann BG, Fischer TM, Haug B, Birchmeier $\mathrm{C}$, et al. Axonal neuregulin-1 regulates myelin sheath thickness. Science. 2004 Apr 30;304(5671):700-3.

10. Aloisi F. Growth factors. Neurol Sci. 2003 Dec;24 Suppl 5:S291-4.

11. Jessen KR, Brennan A, Morgan L, Mirsky R, Kent A, Hashimoto Y, et al. The Schwann cell precursor and its fate: a study of cell death and differentiation during gliogenesis in rat embryonic nerves. Neuron. 1994 Mar;12(3):509-27.

12. Grinspan JB, Marchionni MA, Reeves M, Coulaloglou M, Scherer SS. Axonal interactions regulate Schwann cell apoptosis in developing peripheral nerve: neuregulin receptors and the role of neuregulins. J Neurosci. 1996 Oct 1;16(19):6107-18.

13. Syroid DE, Maycox PR, Burrola PG, Liu N, Wen D, Lee KF, et al. Cell death in the Schwann cell lineage and its regulation by neuregulin. Proc Natl Acad Sci USA. 1996 Aug 20;93(17): 9229-34.

14. Garratt AN, Britsch S, Birchmeier C. Neuregulin, a factor with many functions in the life of a schwann cell. Bioessays. 2000 Nov;22(11):987-96.

15. Morris JK, Lin W, Hauser C, Marchuk Y, Getman D, Lee KF. Rescue of the cardiac defect in ErbB2 mutant mice reveals essential roles of ErbB2 in peripheral nervous system development. Neuron. 1999 Jun;23(2):273-83.

16. Garratt AN, Voiculescu O, Topilko P, Charnay P, Birchmeier C. A dual role of erbB2 in myelination and in expansion of the schwann cell precursor pool. J Cell Biol. 2000 Mar 6;148(5):1035-46.

17. Guertin AD, Zhang DP, Mak KS, Alberta JA, Kim HA. Microanatomy of axon/glial signaling during Wallerian degeneration. J Neurosci. 2005 Mar 30;25(13):3478-87.

18. Hammarberg H, Risling M, Hokfelt T, Cullheim S, Piehl F. Expression of insulin-like growth factors and corresponding binding proteins (IGFBP 1-6) in rat spinal cord and peripheral nerve after axonal injuries. J Comp Neurol. 1998 Oct 12;400(1):57-72.

19. Meier C, Parmantier E, Brennan A, Mirsky R, Jessen KR. Developing Schwann cells acquire the ability to survive without axons by establishing an autocrine circuit involving insulin-like growth factor, neurotrophin-3, and platelet-derived growth factor-BB. J Neurosci. 1999 May 15;19(10):3847-59.

20. Lobsiger CS, Schweitzer B, Taylor V, Suter U. Platelet-derived growth factor-BB supports the survival of cultured rat Schwann cell precursors in synergy with neurotrophin-3. Glia. 2000 May; 30(3):290-300

21. Oya T, Zhao YL, Takagawa K, Kawaguchi M, Shirakawa K, Yamauchi T, et al. Platelet-derived growth factor-b expression induced after rat peripheral nerve injuries. Glia. 2002 Jun;38(4): 303-12.

22. Jessen KR, Mirsky R. Schwann cells and their precursors emerge as major regulators of nerve development. Trends Neurosci. 1999 Sep;22(9):402-10. 
23. Compston A, Zajicek J, Sussman J, Webb A, Hall G, Muir D, et al. Glial lineages and myelination in the central nervous system. J Anat. $1997 \mathrm{Feb} ; 190$ (Pt 2):161-200.

24. Noble M, Murray K, Stroobant P, Waterfield MD, Riddle P. Plateletderived growth factor promotes division and motility and inhibits premature differentiation of the oligodendrocyte/type-2 astrocyte progenitor cell. Nature. 1988 Jun 9;333(6173):560-2.

25. Laeng P, Decimo D, Pettmann B, Janet T, Labourdette G. Retinoic acid regulates the development of oligodendrocyte precursor cells in vitro. J Neurosci Res. 1994 Dec 15;39(6):613-33.

26. Barres BA, Raff MC, Gaese F, Bartke I, Dechant G, Barde YA. A crucial role for neurotrophin-3 in oligodendrocyte development. Nature. 1994 Jan 27;367(6461):371-5.

27. Barres BA, Raff MC. Control of oligodendrocyte number in the developing rat optic nerve. Neuron. 1994 May;12(5):935-42.

28. Fernandez PA, Tang DG, Cheng L, Prochiantz A, Mudge AW, Raff MC. Evidence that axon-derived neuregulin promotes oligodendrocyte survival in the developing rat optic nerve. Neuron. 2000 Oct;28(1):81-90.

29. Colognato H, Baron W, Avellana-Adalid V, Relvas JB, Baron-Van Evercooren A, Georges-Labouesse E, et al. CNS integrins switch growth factor signalling to promote target-dependent survival. Nat Cell Biol. 2002 Nov;4(11):833-41.

30. Kim JY, Sun Q, Oglesbee M, Yoon SO. The role of ErbB2 signaling in the onset of terminal differentiation of oligodendrocytes in vivo. J Neurosci. 2003 Jul 2;23(13):5561-71.

31. Wang S, Sdrulla AD, diSibio G, Bush G, Nofziger D, Hicks C, et al. Notch receptor activation inhibits oligodendrocyte differentiation. Neuron. 1998 Jul;21(1):63-75.

32. Hu QD, Ang BT, Karsak M, Hu WP, Cui XY, Duka T, et al. F3/contactin acts as a functional ligand for Notch during oligodendrocyte maturation. Cell. 2003 Oct 17;115(2):163-75.

33. Fanarraga ML, Griffiths IR, Zhao M, Duncan ID. Oligodendrocytes are not inherently programmed to myelinate a specific size of axon. J Comp Neurol. 1998 Sep 14;399(1):94-100.

34. Friede RL, Bischhausen R. How are sheath dimensions affected by axon caliber and internode length? Brain Res. 1982 Mar 11; 235(2):335-50.

35. Friede RL, Miyagishi T. Adjustment of the myelin sheath to changes in axon caliber. Anat Rec. 1972 Jan;172(1):1-14.

36. Hoke A, Ho T, Crawford TO, LeBel C, Hilt D, Griffin JW. Glial cell line-derived neurotrophic factor alters axon schwann cell units and promotes myelination in unmyelinated nerve fibers. $\mathbf{J}$ Neurosci. 2003 Jan 15;23(2):561-7.

37. Colello RJ, Pott U. Signals that initiate myelination in the developing mammalian nervous system. Mol Neurobiol. 1997 Aug;15(1):83-100.

38. Elder GA, Friedrich VL, Jr., Lazzarini RA. Schwann cells and oligodendrocytes read distinct signals in establishing myelin sheath thickness. J Neurosci Res. 2001 Sep 15;65(6):493-9.

39. Chan JR, Watkins TA, Cosgaya JM, Zhang C, Chen L, Reichardt LF, et al. NGF controls axonal receptivity to myelination by Schwann cells or oligodendrocytes. Neuron. 2004 Jul 22;43(2): 183-91.

40. Chan JR, Cosgaya JM, Wu YJ, Shooter EM. Neurotrophins are key mediators of the myelination program in the peripheral nervous system. Proc Natl Acad Sci U S A. 2001 Dec 4;98(25):14661-8.

41. Cosgaya JM, Chan JR, Shooter EM. The neurotrophin receptor p75NTR as a positive modulator of myelination. Science. 2002 Nov 8;298(5596):1245-8.

42. Notterpek L. Neurotrophins in myelination: a new role for a puzzling receptor. Trends Neurosci. 2003 May;26(5):232-4.

43. Mirsky R, Jessen KR. The neurobiology of Schwann cells. Brain Pathol. 1999 Apr;9(2):293-311.

44. Voyvodic JT. Target size regulates calibre and myelination of sympathetic axons Nature. 1989;342(6248): 430-3.

45. Iwase T, Jung CG, Bae H, Zhang M, Soliven B. Glial cell linederived neurotrophic factor-induced signaling in Schwann cells. J Neurochem. 2005 Sep;94(6):1488-99.

46. Esper RM, Loeb JA. Rapid axoglial signaling mediated by neuregulin and neurotrophic factors. J Neurosci. 2004 Jul 7;24(27):6218-27
47. Stankoff B, Aigrot MS, Noel F, Wattilliaux A, Zalc B, Lubetzki C. Ciliary neurotrophic factor (CNTF) enhances myelin formation: a novel role for CNTF and CNTF-related molecules. J Neurosci. 2002 Nov 1;22(21):9221-7.

48. Cellerino A, Carroll P, Thoenen H, Barde YA. Reduced size of retinal ganglion cell axons and hypomyelination in mice lacking brain-derived neurotrophic factor. Mol Cell Neurosci. 1997;9(56):397-408

49. Esper RM, Pankonin MS, Loeb JA. Neuregulins: versatile growth and differentiation factors in nervous system development and human disease. Brain Res Brain Res Rev. 2006 Aug;51(2): 161-75.

50. Falls DL. Neuregulins: functions, forms, and signaling strategies. Exp Cell Res. 2003 Mar 10;284(1):14-30.

51. ffrench-Constant $\mathrm{C}$, Colognato $\mathrm{H}$, Franklin RJ. Neuroscience. The mysteries of myelin unwrapped. Science. 2004 Apr 30; 304(5671):688-9.

52. Bermingham-McDonogh O, Xu YT, Marchionni MA, Scherer SS. Neuregulin expression in PNS neurons: isoforms and regulation by target interactions. Mol Cell Neurosci. 1997;10(3-4):184-95.

53. Chen S, Velardez MO, Warot X, Yu ZX, Miller SJ, Cros D, et al. Neuregulin 1-erbB signaling is necessary for normal myelination and sensory function. J Neurosci. 2006 Mar 22;26(12):3079-86.

54. Chun SJ, Rasband MN, Sidman RL, Habib AA, Vartanian T. Integrin-linked kinase is required for laminin-2-induced oligodendrocyte cell spreading and CNS myelination. J Cell Biol. 2003 Oct 27;163(2):397-408.

55. Ishibashi T, Dakin KA, Stevens B, Lee PR, Kozlov SV, Stewart CL, et al. Astrocytes promote myelination in response to electrical impulses. Neuron. 2006 Mar 16;49(6):823-32.

56. Waxman SG, Ritchie JM. Molecular dissection of the myelinated axon. Ann Neurol. 1993 Feb;33(2):121-36.

57. Poliak S, Peles E. The local differentiation of myelinated axons at nodes of Ranvier. Nat Rev Neurosci. 2003 Dec;4(12):968-80.

58. Salzer JL. Polarized domains of myelinated axons. Neuron. 2003 Oct 9;40(2):297-318.

59. Vabnick I, Novakovic SD, Levinson SR, Schachner M, Shrager P. The clustering of axonal sodium channels during development of the peripheral nervous system. J Neurosci. 1996 Aug 15;16(16): 4914-22.

60. Vabnick I, Messing A, Chiu SY, Levinson SR, Schachner M, Roder $\mathrm{J}$, et al. Sodium channel distribution in axons of hypomyelinated and MAG null mutant mice. J Neurosci Res. 1997 Oct 15; 50(2):321-36.

61. Arroyo EJ, Sirkowski EE, Chitale R, Scherer SS. Acute demyelination disrupts the molecular organization of peripheral nervous system nodes. J Comp Neurol. 2004 Nov 22; 479(4):424-34.

62. Dugandzija-Novakovic S, Koszowski AG, Levinson SR, Shrager P. Clustering of $\mathrm{Na}+$ channels and node of Ranvier formation in remyelinating axons. J Neurosci. 1995 Jan;15(1 Pt 2):492-503.

63. Kaplan MR, Cho MH, Ullian EM, Isom LL, Levinson SR, Barres BA. Differential control of clustering of the sodium channels $\mathrm{Na}(\mathrm{v}) 1.2$ and $\mathrm{Na}(\mathrm{v}) 1.6$ at developing CNS nodes of Ranvier. Neuron. 2001 Apr;30(1):105-19.

64. Kaplan MR, Meyer-Franke A, Lambert S, Bennett V, Duncan ID, Levinson SR, et al. Induction of sodium channel clustering by oligodendrocytes. Nature. 1997 Apr 17;386(6626):724-8.

65. Eshed Y, Feinberg K, Poliak S, Sabanay H, Sarig-Nadir O, Spiegel I, et al. Gliomedin mediates Schwann cell-axon interaction and the molecular assembly of the nodes of Ranvier. Neuron. 2005 Jul 21;47(2):215-29.

66. de Waegh SM, Lee VM, Brady ST. Local modulation of neurofilament phosphorylation, axonal caliber, and slow axonal transport by myelinating Schwann cells. Cell. 1992 Feb 7; 68(3):451-63.

67. Brady ST, Witt AS, Kirkpatrick LL, de Waegh SM, Readhead C, Tu $\mathrm{PH}$, et al. Formation of compact myelin is required for maturation of the axonal cytoskeleton. J Neurosci. 1999 Sep 1; 19(17):7278-88 
68. Sanchez I, Hassinger L, Paskevich PA, Shine HD, Nixon RA. Oligodendroglia regulate the regional expansion of axon caliber and local accumulation of neurofilaments during development independently of myelin formation. J Neurosci. 1996 Aug 15; 16(16):5095-105.

69. Henderson CE. Role of neurotrophic factors in neuronal development. Curr Opin Neurobiol. 1996 Feb;6(1):64-70.

70. Moore MW, Klein RD, Farinas I, Sauer H, Armanini M, Phillips H, et al. Renal and neuronal abnormalities in mice lacking GDNF. Nature. 1996 Jul 4;382(6586):76-9.

71. Wilkins A, Majed H, Layfield R, Compston A, Chandran S. Oligodendrocytes promote neuronal survival and axonal length by distinct intracellular mechanisms: a novel role for oligodendrocyte-derived glial cell line-derived neurotrophic factor. J Neurosci. 2003 Jun 15;23(12):4967-74.

72. De Stefano N, Matthews PM, Fu L, Narayanan S, Stanley J, Francis GS, et al. Axonal damage correlates with disability in patients with relapsing-remitting multiple sclerosis. Results of a longitudinal magnetic resonance spectroscopy study. Brain. 1998 Aug;121 (Pt 8):1469-77.
73. Ferguson B, Matyszak MK, Esiri MM, Perry VH. Axonal damage in acute multiple sclerosis lesions. Brain. 1997 Mar;120 (Pt 3): 393-9.

74. Sarchielli P, Greco L, Stipa A, Floridi A, Gallai V. Brain-derived neurotrophic factor in patients with multiple sclerosis. J Neuroimmunol. 2002 Nov;132(1-2):180-8.

75. Linker RA, Maurer M, Gaupp S, Martini R, Holtmann B, Giess R, et al. CNTF is a major protective factor in demyelinating CNS disease: a neurotrophic cytokine as modulator in neuroinflammation. Nat Med. 2002 Jun;8(6):620-4.

76. Kuhlmann T, Remington L, Cognet I, Bourbonniere L, Zehntner S, Guilhot F, et al. Continued administration of ciliary neurotrophic factor protects mice from inflammatory pathology in experimental autoimmune encephalomyelitis. Am J Pathol. 2006 Aug;169(2):584-98.

77. Baron $\mathrm{W}$, Colognato $\mathrm{H}$, ffrench-Constant $\mathrm{C}$. Integrin-growth factor interactions as regulators of oligodendroglial development and function. Glia. 2005 Mar;49(4):467-79. 